Committee on Local OrBanizations--Annual Report Submitted to the Board of Directors, May 21, 1907

The Committee on Local Organizations would submit the following report on the Branch situation and of the work of the committee during the last year.

There are at present a total of 33 Local Organizations included under the head of Branches, University Branches, and Student Meetings. Of these, 17 are organized in connection with educational institutions, reaching the student membership; the remaining 16 are located in cities as centers of electrical interest for the Members and Associates in their territory. There have been but few additions or changes during the year in the above number of Local Organizations. The University Branch at the University of Illinois, having the number of Members and Associates required by the By-laws, has, by action of the Board of Directors, been made a Branch.

Student Meetings have also, by the approval of the board, been organized as follows: 1906.

University of Maine, December 26,

Montana Agricultural College, March 29, 1907.

The question of the adoption of a student pin and the design for such a pin were submitted to the Board of Directors and approved. These pins are now in the process of manufacture and will be available at the beginning of the next term for students desiring them.

At the beginning of the year there seemed to be a lack of definite understanding as to the publication in the Proceedings of original papers presented at the Branches. A conference on the matter was held with the Editing Committee, as a result of which it was decided to publish meritorious papers read before the Branches, and announcement to that effect was made in the December Procendings.

Your committee feels that a reference should be made to the help afforded by the Branches in obtaining a vote for the revised Constitution. The cooperation of the Branches was enlisted for this purpose and a direct appeal to vote was made by the managers of the different local organizations to their membership. If a large enough vote is obtained on the Constitution for decisive action, considerable credit, we feel, should be given to the Branches. The Institute should also make note of the value of such organizations as a means of reaching a scattered membership.

The work done by the Branches themselves in the holding of engineering meetings and in the presentation and discussions of papers has undoubtedly been more successful this year than ever before. The following table of statistics will show, to some extent, the activities in this direction during the year:

$$
\begin{aligned}
& \text { No. of } \\
& \text { meetings Average No. of } \\
& \text { since attend- original } \\
& \text { Sept. '06. ance. papers. }
\end{aligned}
$$

\begin{tabular}{|c|c|c|c|}
\hline Atlanta............. & - & - & - \\
\hline Baltimore........... & 7 & 45 & 7 \\
\hline Boston........... & 7 & 117 & 6 \\
\hline Chicago........... & 5 & 95 & 5 \\
\hline Cincinnati......... & 5 & 20 & 4 \\
\hline Columbus......... & 7 & 15 & 1 \\
\hline Minnesota........ & 10 & 40 & 12 \\
\hline Pittsburg......... & 7 & 73 & 4 \\
\hline Pittsfield......... & 6 & 27 & 3 \\
\hline Philadelphia....... & 7 & 73 & 12 \\
\hline San Francisco....... & 一 & - & - \\
\hline Schenectady....... & 28 & 275 & 18 \\
\hline Seattle.......... & 5 & 17 & 3 \\
\hline St. Louis. . . . . . . . & 7 & 25 & $\mathbf{5}$ \\
\hline Toronto........... & 3 & 28 & - \\
\hline Washington, D. C... & 4 & 44 & 一 \\
\hline Cornell University. . . & 8 & 130 & 4 \\
\hline Iowa State College... . & 13 & 25 & 10 \\
\hline Lehigh University... & 8 & 40 & 20 \\
\hline Purdue University... & 12 & 100 & 7 \\
\hline Syracuse University. & 12 & 20 & 9 \\
\hline Univ. of Wisconsin. . & 6 & 60 & 5 \\
\hline Univ. of Illinois.... & 8 & 62 & 2 \\
\hline Worcester Poly. Inst. & 7 & 46 & 11 \\
\hline Armour Institute... & 9 & 30 & - \\
\hline Ohio State Univ..... & 1 & 18 & - \\
\hline Penn. State College.. & 一 & 一 & - \\
\hline Univ. of Arkansas... & 12 & 30 & 一 \\
\hline Univ. of Colorado.... & - & - & - \\
\hline Univ. of Michigan... & 一 & 一 & - \\
\hline Univ. of Missouri... . & 10 & 20 & - \\
\hline Washington Univ.... & 3 & 8 & \\
\hline
\end{tabular}


It is evident from the above table that the Branches are carrying out the work which was the idea of their foundation. They have practically all been in existence for three or four years; the first flush of enthusiasm that may have existed at their formation has had time to cool; the leaders who were responsible for the starting of a Branch have, in most cases, passed on the work to other hands; and the fact that the work continues to flourish and the interest remains unabated, shows that the Branch movement has passed a formative period and has settled down to a working basis.

It is noticeable from the table that the meetings have been held with regularity and that the attendance has been large. The average attendance in percentage of the available membership will compare very favorably with that of the New York meetings. It is also noticeable that more attention has been given to the presentation of original matter and less to the consideration of the New York papers than in former years.

The committee has been much impressed with the activity of the University Branches and Student Meetings. Their work differs essentially from that of the regular Braches in that it is largely educational. Their function is to assist in the development of younger men and to bring them into touch with the Institute at the threshold of their careers. How well they are doing this work and the importance of encouraging it can be estimated from the number of young men who are being reached in this way. The statistics speak for themselves.

Cornell shows an average attendance at its meetings of 130 with a maximum of 225; Purdue, an average of 100 , a maximum of 265; Wisconsin, average 60 , maximum 175 .

In fact, virtually all of the University Branches show that the Students of the Institute are taking an active interest in the work. The following quotation from a letter received from Professor
Esty of Lehigh University expresses very well the general situation at these organizations:

Our year just closing has been the most successful in our history. I regard the social feature of our monthly meetings as a most important element in stimulating interest. We are training our students to become active and useful future members of the Institute. Local organizations of this kind certainly pay enormous dividends on the investment.

Letters were sent to the Branches asking for an expression of opinion as to the year's work and as to future prospects. In answer to the question; "Has the current year been successful and shown a healthful increase in interest and activity?" the reply has almost invariably been an emphatic "Yes." Judging from the reasons given in these replies, this success has been due to the following causes and in about the order of importance as stated:

1. To an enthusiastic and hard working set of men at the head of the Branch.

2. To the consideration of original papers of local interest instead of a rehash of the New York papers.

3 . To the increased recognition of the Branches by the Institute.

4. To the development of a certain amount of social features.

The replies to the question: "What is most needed to further the interest of the Local Organizations?" have shown a remarkable unanimity. Some say that a larger appropriation from the Institute funds is required to permit an expansion of the work, the hiring of better meeting quarters, and an increase of social features. Practically all are united in saying that there is needed a greater coöperation between the Branches and the Institute. All believe that occasional visits to the Branches by officers and prominent members of the Institute would increase the enthusiasm of the Branches themselves and would strengthen the bond between them and the Institute.

The above digest of the replies of 
the Branches to these two important questions which are in effect: "How has success been attained in the past?" and "How can it be continued and increased in the future?" would seem to indicate that the $e_{1}$ is necessarily a development along two lines:

1. In order that the work done by the Branches can be of any value at all, either to themselves or to the Institute, they must be encouraged to develop as strong local societies.

2 . In order that these local centers may be part and parcel of the Institute and may add strength rather than weakness to it, there must at the same time be developed a spirit of unity and coöperation between these scattered and distant organizations and the main body of the Institute.

The first line of development is largely in the hands of the Branches themselves; they must justify their existence by their results. The clauses in reference to the local organizations in the revised Constitution are very broad in their features and will permit any Branch to work along the lines best suited to its locality. The following would seem to be some of the conditions bearing on the possibility of local success:

There should first of all be a large enough membership in the territory properly belonging to a Branch to enable the work to be carried on without its being necessary to depend on two or three enthusiasts. The present Bylaws require ten Members and Associates as the minimum number for the formation of a Branch. This number we believe to be too low and wou'd recommend that it be increased to at least twenty-five. This, of course, does not apply to University Branches or Student Meetings. Their formation should, in the future, as heretofore, be encouraged in any institution of recognized standing.

Branches should take their work seriously, and should organize with offcers and committees chosen with that end in view. It is particularly important that officers for the ensuing year should be selected before the summer vacation, so that they may be ready to take hold vigorously with the opening of the work in the autumn.

As definite a program as possible should be laid out early in the year. It may be more or less tentative and changed as the year progresses, but a plan to work by will both lessen the burden of the work and insure more interesting meetings.

Younger men should be encouraged to take a prominent part, so that they can be fitted to become officers of the Branches, bringing in new ideas and relieving those who have been carrying on the work.

The consideration of original papers will be found necessary in order to keep up the interest.

Social features and visits of prominent engineers will also add very much to the interest of the work, but are largely a matter of expense.

The expense question is always a difficult one to handle. The funds of the Institute are limited, and on account of the number of Branches it is difficult to appropriate for each Branch a sum sufficiently large to satisfy all of its requirements. The necessary expenses for engineering meetings, such as the rent for a hall, the cost of sending out notices, and of a stenographer at the meetings, should be met from the Institute funds. To a certain extent we believe it would be wise for the Institute to bear the expense in connection with visiting engineers. The expense of social features should be paid out of local funds and not charged against the Institute.

In order to strengthen the bond of unity and coopperation between the Branches and the Institute, there should certainly be continued the liberal attitude which has been shown by the administration this year. The publication of meritorious Branch papers in the Procendings will help along these lines. The larger publicity to Branch 
affairs which has been given in this year's PROCEedings has undoubtedly been of great assistance in strengthening the Branch work. The Branches can be further made to feel that they are an integral part of the Institute, if they are asked to assist, as far as possible, in the work of the Institute. They should be represented on committees, and with due regard to the possibility of assembling a working quorum they should be represented on the Board of Directors. Personal visits to the Branches on the part of officers and prominent members would be most helpful in bringing about this feeling of coöperation.

In conclusion we would bring to the attention of the Institute at large, and especially to any members who may have any doubts as to the wisdom of encouraging the Branch work, the fact that this work can be no longer considered as in an experimental or temporary stage. The wisdom of starting the Branch movement is no longer a proper question for debate: the Branches are here with an immense possibility for useful work. It is not conceivable that this work started in the broadest spirit of the greatest good to the entire membership of the Institute can be allowed to languish through a lack of appreciation of its pcssibilities or through a lack of coöperation either on the part of the Branches themselves or on the part of the main body of the Institute.

For the Committee on Local Organizations.

Paul Spencer, Chairman.

\section{Sections and University Branches}

Toledo Section

The regular monthly meeting of Toledo Section, was held August 2, 1907 , at the Boody House. The secretary, Geo. E. Kirk, presided owing to absence of the chairman.

After transacting routine business, Dr. Lee DeForest was introduced.
The address given by Dr. DeForest was most clear and entertaining, accompanied by sketches on the blackboard. The sensitiveness of the arc to electric waves, and the adaptation of this scheme to space or wireless signaling was outlined, followed by references to coherer, polariphone, and other instruments for similar purposes, including the audion.

The general circuits were explained, and the methods of tuning, which may be such as to permit quite a number of stations in overlapping fields without interference. The advantages of the wireless telephone over the wireless telegraph, were compared as the wire telephone to that of wire telegraph.

On invitation of Dr. DeForest, after the meeting the members were given an opportunity to visit the wireless telephone station in the Ohio Building, Toledo, where receiving and transmitting was conducted by those present with a station some two blocks distant in the Nicholas Building. Besides conversing, a phonograph rendered several selections from the Nicholas station, showing the transmission to be most accurate. These stations are to be used in developing the wireless telephone on the great lakes.

The Section adjourned to meet the first Friday in September.

\section{Associates Ilected}

At a regular meeting of the Board of Directors held in the Engineers' Building, 33 West Thirty-ninth street, New York, Friday, August 30, 1907, at $3: 30$ p.m., the following 55 Associates were elected:

Adams, Arthur L., Malden Electric Co.; res., 70 Linden Ave., Malden, Mass.

Barfoed, Svend, Draftsman, F. G. Baum \& Co., 1406 Chronicle Bldg., San Francisco, Cal.

Biegler, Philip Sheridan, Instructor in Electrical Engineering, State University of Iowa, Iowa City, Iowa. 